\title{
Вера Антропова
}

Челябинский государственный университет

iD

ORCID https://orcid.org/0000-0003-3421-9978

\section{Василий Федоров}

Челябинский государственный университет

iD

ORCID https://orcid.org/0000-0001-6295-5054

\section{КОГНИТИВНО-НАРРАТИВНАЯ РЕАЛИЗАЦИЯ КОНЦЕПТОВ «СОВЕСТЬ» И «ДОБРО» В ДУСКУРСЕ ЛИТЕРАТУРНЫХ ЖУРНАЛОВ}

\author{
COGNITIVE AND NARRATIVE IMPLEMENTATION OF THE CONCEPTS \\ OF “CONSCIENCE” AND “GOOD” IN THE DISCOURSE OF LITERARY JOURNALS
}

\begin{abstract}
The article deals with the problem of value transformations in modern Russian society, the translator of which are "thick" literary and social and political journals. The authors explore this process by analyzing the cognitive and narrative mechanisms implementing the concepts of "conscience" and "good" in magazines.
\end{abstract}

Keywords: axiology, narrative, cognitive script, literary journals, Russian society.

POZNAWCZO-NARRACYJNA REALIZACJA POJĘĆ „SUMIENIE” I „DOBRO” W DYSKURSIE CZASOPISM LITERACKICH

Artykuł porusza problem przemian wartości we współczesnym społeczeństwie rosyjskim, których nośnikami stają się literackie, artystyczne, społeczne i polityczne „tołstyje żurnały”. Autorzy badają ten proces, analizując poznawczo-narracyjne mechanizmy realizacji pojęć „sumienie” i „dobro", przejawiających się w dyskursie tychże czasopism.

Słowa kluczowe: aksjologia, narracja, skrypt poznawczy, czasopisma literackie, społeczeństwo rosyjskie.

Аксиологический кризис во всех сферах жизни российского общества привел к ценностной доминанте научных изыска- 
ний в области гуманитаристики. Философы, культурологи, социологи оценивают современную ситуацию как «ценностный вакуум», «ценностно-нормативную неопределенность», «ценностный релятивизм и нигилизм», обусловленные «общим снижением ценностного статуса морали, нравственности, размытостью ориентиров в понимании добра и зла», «упадком социального авторитета традиционных ценностей», «профанизацией идеи личной ответственности и личного выбора» ${ }^{2}$. Динамика же такова, что в России эти процессы «идут в направлении усиления дифференциации и плюрализации нормативно-ценностных систем»².

Журналистика как социальный институт и журналистское творчество как вид креативной деятельности по природе своей были и остаются ценностно маркированными, и сегодня в рамках журналистской науки, по мнению некоторых специалистов, возникла даже отдельная учебная дисциплина и научная парадигма - аксиология журналистки (Виктор Александрович Сидоров, Камилла Ренатовна Нигматуллина, Сергей Сергеевич Ильченко), призванная в ситуации культурного многообразия отразить ценностный конфликт медийной реальности.

Уникальным продуктом современной медиакультуры являются так называемые «толстые» отечественные журналы типа «Октябрь», «Звезда», «Дружба народов», «Нева», «Новый мир», «Знамя», «Наш современник» и некоторые другие, восходящие к литературным, сатирическим и энциклопедическим журналам XVIII-XIX веков, а позже - к советским «толстым» журналам. Советские «толстые» журналы задумывались, с одной стороны, как преемники дореволюционных журналов, с другой - это было принципиально новое куль-

${ }^{1}$ Т.В. Тилинина, Причины кризиса иенностных ориентаций в современных российских семьях // «Теория и практика общественного развития» 2012, № 6, http://teoria-practica.ru/rus/files/arhiv_zhurnala/2012/6/sociologiya/tilinina.pdf (5.01.2019).

${ }^{2}$ С.В. Мареева, Динамика норм и иенностей россиян // «Социс» 2013, № 7, c. 120 . 
турно-эстетическое явление в журнальном поле советской печати, поскольку они возникли именно в 20-30-е годы XX века как «создатели и выразители государственной политики в области культуры», призванные «наиболее эффективно воздействовать на общественное сознание» ${ }^{3}$. И несмотря на то, что подобные ежемесячные литературно-художественные и общественно-политические журналы представляют собой сегодня отдельный - элитарный - сегмент журнальной периодики России, противостоящий другим информационным потокам, даже в его структуре наблюдается идеологическая и культурно-эстетическая дискретность и разобщенность. Так, с одной стороны, находятся радикальные, оппозиционные издания, проводящие идеологию национального консерватизма, поддерживающие традиционные патриархальные ценности («Наш современник»), с другой стороны, журналы, ориентированные на западные либерально-демократические идеалы («Знамя»). «Наш современник», первоначально печатавший представителей «деревенской прозы» - Федора Абрамова, Василия Белова, Сергея Залыгина, Валентина Распутина, Владимира Солоухина, Василия Шукшина - объявил себя «трибуной виднейших политиков патриотического направления», оппозицией прозападным установкам, «ведущим к разрушению России и гибели русского народа»4. Журнал «Знамя», задуманный как издание литературного объединения Красной Армии и Флота, с 1934 по 1990 годы был органом Союза писателей СССР, где, наряду с писателями соцреализма, печатались также Андрей Платонов, Юрий Тынянов, Александр Твардовский, Виктор Некрасов, Юрий Казаков, Константин Симонов, Юрий Трифонов, Виктор Астафьев, Варлам Шаламов, позже - Булат Окуджава, Фа-

\footnotetext{
${ }^{3}$ И.В. Шкаровская, Становление и развитие советских «толстых» журналов в первой половине 20-х годов: автореф. дис. канд. филол. наук, Москва 1999, http://cheloveknauka.com/stanovlenie-i-razvitie-sovetskih-tolstyhzhurnalov-v-pervoy-polovine-20-h-godov (5.01.2019).

${ }^{4}$ Официальный сайт журнала «Наш современник»: http://www.nash-sovremennik.ru (5.01.2019).
} 
зиль Искандер, Людмила Петрушевская, Владимир Маканин, Георгий Владимов, Василий Аксенов, Владимир Войнович. В 1990 году СМИ «объявило себя независимым, отстояв свои права в полуторалетней судебной тяжбе с Союзом писателей СССР ${ }^{5}$; постепенно превратилось в «издание, последовательно утверждающее идеалы демократии и отечественного либерализма» ${ }^{6}$.

Таким образом, нам представляется целесообразным рассмотреть когнитивные и нарративные механизмы воплощения некоторых базовых ценностей в текстах двух журналов, состоящих в оппозитивных отношениях. В качестве базовых обратимся к двум сопряженным ценностям этического толка: «добро» и «совесть». В такой связке мы их рассматриваем в силу их комплетивно-инструментальных (то есть дополнительно-вспомогательных) отношений: мерилом «добра» является то, что не противоречит «совести», иными словами, «совесть» становится этическим основанием измерения, понимания «добра», различения «добра» и «зла».

Методологическим инструментом изучения ценностей в текстах выбранных печатных СМИ стал концеп т - когнитивная (мыслительная) категория, оперативная единица «памяти культуры», квант знания; сложное, нежестко структурированное смысловое образование описательно-образного и ценностно-ориентированного характера ${ }^{7}$. Концепт методологически релевантен описанию ценностных трансформаций, поскольку имеет ядерно-периферийную организацию: ядро структуры - это центральные, инвариантные смысловые компоненты, характеризующиеся семантической стабильностью, а элементы периферии обладают ослабленной, опосредованной (часто ассоциативной, метафорической, этимологической и т.д.) семантической связью с центром. Принцип полевого

${ }^{5}$ Официальный сайт журнала «Знамя»: http://znamlit.ru (5.01.2019).

${ }^{6}$ «Знамя»: очерк истории, http://znamlit.ru/history.html (5.01.2019).

${ }^{7}$ Н.Ф. Алефиренко, Поэтическая энергия слова. Синергетика языка, сознания и культурь, Academia, Москва 2002, с. 17. 
структурирования концепта поддерживается абсолютным большинством российских лингвоконцептологов (Зинаида Даниловна Попова, Иосиф Абрамович Стернин, Сергей Григорьевич Воркачев, Николай Федорович Алефиренко, Владимир Ильич Карасик, Геннадий Геннадьевич Слышкин, Григорий Валерьевич Токарев).

Для фиксации определенных ценностно-смысловых трансформаций сначала конструируют общеязыковую, узуальную (то есть восстановленную по историческим и современным словарям) модель концептов, затем - дискурсивные модели с целью дальнейшего сравнения и определения смысловой динамики.

Итак, узуальная модель концепта «совесть», по данным лексикографических источников ${ }^{8}$, выглядят следующим образом:

- ядерная зона: 1. «чувство и сознание моральной ответственности за свое поведение и поступки перед самим собой, перед окружающими людьми, обществом»; 2. «нравственные принципы, взгляды, убеждения»;

- околоядерная зона: «средство апелляции к нравственноэтическим нормам с целью выявить несоответствие этим нормам и вызвать чувство стыда». Очевидно, что ядерные концептуальные признаки описывают нравственно-этические

\footnotetext{
${ }^{8}$ К.С. Горбачевич, Словарь эпитетов русского литературного языка, Норинт, Санкт-Петербург 2002; М.Р. Львов, Словарь антонимов русского языка: более 2000 антоним. пар, Русский язык, Москва 1984; В.А. Маслова, Лингвокультурология, Издательский центр «Академия», Москва 2001; С.И. Ожегов, Н.Ю. Шведова, Толковый словарь русского языка: 80000 слов и фразеол. выражений, Азбуковник, Москва 1999; Ю.Н. Караулов, Г.А. Черкасова, Н.В. Уфимцева, Ю.А. Сорокин, Е.Ф. Тарасов, Русский ассоииативный словарь: в 2-х т., АСТ-Астрель, Москва 2002; Л.В. Грехнева, Т.М. Горшкова, Е.Р. Переслегина, Л.И. Ручина, А.В. Синелева, Словарь кониептов русской народной сказки: в 2-х ч., Изд-во Нижегород. ун-та, Нижний Новгород 2011, 2015; А.П. Евгеньева (ред.), Словарь русского языка: в 4-х т., Полиграфресурсы, Москва 1999; той же (ред.), Словарь синонимов русского языка, АСТ, Москва 2003; П.Н. Денисова, В.В. Морковкин, Словарь сочетаемости слов русского языка, АСТ, Москва 2005; М. Фасмер, Этимологический словарь русского языка, пер. О.Н. Турбачев, АСТАстрель, Москва 2007.
} 
принципы личности с точки зрения индивидуального контроля (человек сам контролирует свое поведение, осуществляет рефлексию собственных действий), а приядерные - с точки зрения социального контроля (окружающие оценивают поступки индивида, общество показывает ему правильный вариант). При этом наличие совести и ее отсутствие в языковой картине мира однозначно соотнесены с бинарными оппозициями «хорошо/плохо» и «правильно/неправильно»;

- периферийная зона (принимались во внимание данные ассоциативных, этимологических словарей, словарей эпитетов): 1. «нечто, доставляющее физический или психологический дискомфорт» (больная, взбаламученная, возмущенная, неспокойная, потревоженная, растревоженная, щекотливая, мучает, грызет, гложет, жгучая); 2. «что-то, связанное с восприятием чистоты, света» (кристальная, кристальночистая, незапятнанная, нечистая, черная, чистая, непогрешимая, свет); 3. «нечто, что имеет физические характеристики» (глубокая, глухая, растяжимая, бездонная, глиняная, чугунная, резиновая); 4. «связанное с профессиональным долгом» (врачебная, общественная, партийная, политическая, юридическая, чекиста); 5. «связанное с состоянием сна и памяти» (дремлющцая, пробудившаяся, проснувшаяся, забъьвивая, спит); 6. «лицемерие, неискренность вследствие утраты» (продажная, сговорчивая, потерянная, проданная, змеиная); 7. «то, что является пережитком прошлого, что уже не востребовано; никому ненужный идеал» (в шкафу на вешалке, мечта идиота, советского человека, фбантом); 8. «то, что имеет временную характеристику» (эпохи, нетленная, давно); 9. «связанное с владением информацией» (знать, ведать). Таким образом, периферийная зона снимает незыблемую императивность и константность «совести», в данной части поля эта ценность представлена относительно: совесть не всегда нужна, она темпорально обусловлена, она вызывает болезненные ощущения, можно пойти на сделку с собственной совестью, это средство ввести в заблуждение человека и т.д. 
По такому же принципу охарактеризуем общеязыковую модель концепта «добро»:

- ядерная зона: «все положительное, хорошее, то, что противопоставлено злу»;

- околоядерная зона: 1. «то, что приносит пользу»; 2. «вещи, имущество»; 3. «согласие на что-либо, одобрение поступка»; 4. «очень хорошее качество». Таким образом, если ядерная семантика имеет все же абстрактный характер и концепирует «добро»с точки зрения «отвлеченной» этики, то околоядерные компоненты встраивают «добро» в повседневно-практическую область деятельности человека, связанную с прагматикой его поступков, социальной коммуникацией, материальным достатком и т.д.;

- зона периферии: 1. «вежливое, ласковое, приветливое отношение к кому-либо; благожелательность по отношению к кому-либо» (добро пожаловать, мама, ульбка, нежность, радость); 2. «все, что связано с течением времени, прошлым, памятью» (детство, старость, на век, вечно, память); 3. «то, что в дефиците» (редко, редкость, кончается); 4. «то, что доставляет эстетическое удовольствие, на что приятно смотреть» (ияеты, сон, красота); 5. «основательность результатов труда» (кузнеи, ремесленник, художник); 6. «то, что доставляет физическое удовольствие» (выпивка, в штанах).

Теперь перейдем к дискурсивной реализации концептов (для анализа был взят весь массив публицистических текстов за 2016 год из названных журналов, вербализующих данные концепты). Для начала представим количественные характеристики признаков концептов «совесть» и «добро»:

Параметр

«Знамя»

10

23
«Наш современник»

Количество репрезентантов

(вербализаторов, объективаторов)

концепта «совесть»

концепта «добро» 
Количество контекстов

(случаев реализации,

употреблений)

концепта «совесть»

43

8

концепта «добро»

Количество выявленных

семантических признаков (групп,

смыслов)

концепта «совесть»

концепта «добро»

6

10
4

6

Вполне очевидна общая тенденция в концептуализации указанных ментальных конструктов: так называемый концепт«средство» («совесть») представлен в гораздо меньшей степени, чем концепт-«следствие» («добро»), что говорит о несформулированности, размытости, невнятности самих измерительных средств, методов, способов, с помощью которых постигаются ценности, имеющие более отвлеченный характер.

Что же касается качественных показателей, то реконструкция модели концепта «совесть» в дискурсе журнала «Знамя» показала следующее: произошло совпадение ядерного дискурсивного смысла «нравственный закон, регулирующий поведение человека» (14 контекстов) с идентичным в узусе (то есть в языковой картине мира), что свидетельствует об универсальности рассматриваемого концепта и вместе с тем - низком потенциале образования новых смыслов. Однако обнаружен один новый околоядерный компонент «форма организации деятельности высокого качества» (11 текстовых фрагментов), не встретившийся ранее в описании узуальной модели. Это позволяет сделать предположение о трансформации смыслов, тенденции перехода семантики из сферы «отвлеченной» нравственности в предметную плоскость показателя качества деятельности кого-либо. Таким образом, в качестве когнитивной стратегии ценностной трансформации мы отмечаем коннотативность, оценочность «совести», так как этико-нравственная семантика уступает место семантике оценки качества, обладающей исчисляемостью, прагматической изменяемостью. 
Журнал «Наш современник» в гораздо меньшей степени апеллирует к концепту «совесть» и рассматривает его исключительно в рамках традиционной когнитивной матрицы, где присутствуют все общеязыковые семантические элементы: «нравственный гарант справедливости и правдивости» (6 контекстов), «честность, порядочность» (3), «ответственность за принятие решения» (3).

Объективация концепта «добро» в журнале «Знамя» говорит об отсутствии каких-либо изменений в ядре и приядерной части, так как центральный смысл «что-либо положительное, противопоставленное злу» с рекордно частотным показателем (81 контекст) заполнил практически все семантическое пространство, «поглотив» даже околоядерную часть, журнал экстраполировал этот важный и единственный смысл на большой фрагмент поля. Это свидетельствует о том, что концепт «добро» даже в дискурсе элитарного журнала «Знамя» «законсервировался», новых тенденций в развитии его ценностного потенциала издание пока не видит. Не видит, как нам представляется, по нескольким причинам: 1. само содержание этой ценности сегодня сколько-нибудь внятно не сформулировано, поэтому журнал максимально осторожно, следуя аксиологическим традициям русской культуры, ретранслирует семантику «добра» и тем самым поддерживает общеязыковую картину мира; 2. именно «добро», как никакая другая ценность, сегодня особенно заметно подвергается аксиологическому выхолащиванию и релятивизму, в связи с чем издание пошло по пути репродукции, упрощения и закрепления ценностного содержания (один базовый смысл заполнил одновременно ядерную и приядерную зоны).

Аналогичную картину, следуя качественным показателям, можно наблюдать и в отношении этого же концепта в дискурсе «Нашего современника»: с большим перевесом лидирует смысловой компонент «что-либо положительное, противопоставленное злу» (16 контекстов). Количественные же данные свидетельствуют о том, что издание в гораздо меньшей степени актуализирует этот концепт в сознании читателей. 
Таким образом, ценностно-трансформационные процессы по-разному воплотились в дискурсивных практиках «Знамени» и «Нашего современника». «Наш современник» повторил языковую картину мира исходя из закона экономии речевых усилий, тем самым подтвердив статус консервативного издания и по форме, и по содержанию. «Знамя», транслируя содержание концепта «добро», поддержал общеязыковую картину мира, не поддаваясь аксиологическому релятивизму, а в структуре концепта «совесть» актуализировал новое значение положительной оценки качества. С одной стороны, можно говорить об аксиологическом выхолащивании и снижении статуса концепта, что соответствует общекультурной динамике, с другой - о попытке элитарного издания какимто образом актуализировать, реанимировать, «обновить» находящиеся в глубоком кризисе этические ценности.

Материалы, опубликованные в «толстых» литературных журналах, представляют собой вариант нарративного дискурса. Нарративизацию можно рассматривать как способ реализации ценностных смыслов в форме устойчивых повествовательных структур. В этом отношении тексты эксплицируют когнитивные (ментальные) модели.

Изучение нарративных механизмов началось во второй половине XX века, нарративная теория прошла эволюцию от структуралистского толкования, рассматривающего повествование как структуру, набор отдельных элементов, до когнитивных исследований, в которых изучаются ментальные, психологические и культурологические основания производства нарративов

Используя теорию Тена ван Дейка о соотношении когнитивной (ситуационной) модели и дискурса, мы получим методологический аппарат для описания нарративных стратегий реализации концептов «совесть» и «добро».

Ученый отмечает, что «важнейшим компонентом процессов построения и восприятия текстов является осмысление

9 Д.В. Барышникова, Когнитивный поворот в постклассической нарратологии (Обзор новых англоязычных книг) // «Новое литературное обозрение» 2013, № 119, www.magazines.russ.ru/nlo/2013/119/b32.html (5.01.2019). 
стоящих за ними социальных ситуаций и их когнитивная репрезентация» ${ }^{10}$. Таким образом, возникает оппозиция: реальная социальная ситуация (фрагмент) vs. представление о ней, которая существует в виде сценария, или фрейма, приобретенного в результате социокультурного опыта, и он выступает не только шаблоном для производства нарратива, но своего рода интерпретационной рамкой. Второй элемент определяет построение дискурса (что и как мы будем говорить, сталкиваясь реальной с ситуацией или описывая ее в речи): «Когнитивные модели составляют референциальный базис для интерпретации дискурса, а не 'фрагментов реального мира', или ситуаций» ${ }^{11}$. Это позволяет нам выявить и описать не просто наборы текстов, а сложившиеся в данном типе коммуникации повествовательные структуры, являющиеся матрицей для построения конкретных текстов и транслирующие готовые ментальные и ценностные стереотипы.

Способность повествовательных моделей выступать носителем культурной информации и опыта подтверждает и Уильям Лабов, исследовавший устные рассказы англоязычных респондентов: «These forms of communication may draw upon the fundamental human capacity to transfer experience from one person to another through oral narratives of personal experience» ${ }^{12}$.

Дебора Шиффрин продолжает исследование нарративов, указывая на разработанные Уильямом Лабовом типичные социолингвистические методы. Автор отмечает: «Narrative is a form discourse trough which we reconstruct and represent past experience both for ourselves and for others» ${ }^{13}$. Можно говорить о том, что возникло когнитивное направление в изучении нарративов. В центре исследований оказывается взаимосвязь

${ }^{10}$ Т.А. ван Дейк, Язык. Познание. Коммуникация: сборник работ, ред. пер. В.И. Герасимов, сост. В.В. Петров, Прогресс, Москва, с. 161.

${ }_{11}$ Там же, с. 164.

${ }^{12} \mathrm{~W}$. Labov, Oral narratives of personal experience, http://ling.upenn.edu/ wlabov/Papers/FebOralNarPE.pdf (5.01.2019).

${ }^{13}$ D. Schiffrin, Redoing and replaying // той же, In Other Words: Variation in Reference and Narrative, Cambridge University Press, Cambridge 2006, c. 321. 
социокультурного опыта человека и механизмов его речевой репрезентации.

Для нас важен тезис об изоморфности когнитивных механизмов, отвечающих за построение устных повествований о личном опыте людей, и моделей нарратива в дискурсе «толстых» литературных журналов.

Таким образом, дискурсивная реализация концептов «совесть» и «добро» конструируется посредством нарративных структур, которые задействуют различные смысловые компоненты концептов. Существование таких нарративов определяется наличием типичных историй, или «сюжетов», выступающих культурными единицами коллективного опыта, то есть представляют смыслы и ценности в виде рассказов, которые имеют структурно-содержательное тождество. Наша задача состоит в том, чтобы выявить и описать такой набор нарративов в дискурсе «толстых» литературных журналов, формируемом публицистическими, критическими материалами, определить, каким образом они репрезентируют ценностные трансформации в современном российском обществе.

Опираясь на социокультурную и идеологическую характеристику журналов «Знамя» и «Наш современник», мы можем говорить о различных вариантах нарративизации концептов «совесть» и «добро».

В журнале «Наш современник» концепт «совесть» реализуется в нарративной модели, которая построена на противостоянии и столкновении, реальных и предполагаемых. С одной стороны, это внутренний конфликт, воплощающий ядерный смысл «чувство и сознание моральной ответственности за свое поведение и поступки перед самим собой, перед окружающими людьми, обществом». Например:

Компенсационные лесопосадки в Химках и окрестностях благополучно принялись и обещают вырасти лучше прежних. А что же блудная дочь Химкинского леса? В 2015 году она вместе со своей семьей переехала в Эстонию на постоянное место жительства. Почему? Совесть заела? Не похоже ${ }^{14}$.

${ }^{14}$ И.Т. Янин, Черноморская Пальмира // «Наш современник» 2016, № 9, http://nash-sovremennik.ru/archive/2016/n9/1609-14.pdf (5.01.2019). Все вы- 
С другой стороны, внешний конфликт, объективирующий околоядерный компонент: «средство апелляции к нравственно-этическим нормам с целью выявить несоответствие этим нормам и вызвать чувство стыда», - выполняющий функции социального контроля: «Знает, что новые члены Евросоюза выпрашивают огромные средства, без зазрения совести крича об угрозе» ${ }^{15}$. При этом, в большинстве употреблений конфликт этот только предполагается, но в итоге не осуществляется. Такой устойчивый смысловой компонент («мнимого», «несостоявшегося» конфликта) подчеркивает ориентацию журнала, в дискурсе которого современное общество и отдельный индивид в большинстве своем не встраиваются в традиционные морально-этические принципы, все «иное» (особенно западное) не имеет в своей ценностной иерархии совести. Показателен в этом смысле первый пример, в котором использован библейский интертекст (блудная дочь), демонстрирующий уход от совести, ее потерю. Сам конфликт, «нарратив противостояния», репрезентирует позицию журнала как «форпоста» совести в хаотичной действительности, постоянную его борьбу за совесть. Поэтому в журнале «Наш современник» происходит апелляция к коллективной совести, на это указывает высокая частотность фразеологических и идиоматических единиц (замучила совесть, без зазрения совести).

В дискурсе журнала «Знамя» нарративная репрезентация концепта «совесть» обнаруживает другую закономерность. «Конфликтный сюжет» трансформируется в сюжет о нравственном выборе отдельного человека или героя художественного произведения. Иными словами, совесть предстает как индивидуальный выбор, как решение «Я» соблюдать принципы или отказаться от них:

И почему человеческая природа устроена так, что самыми грешными чувствуют себя вовсе не те, кому это пристало? Почему стыд грызет самых

деления текстовых фрагментов подчеркнутым шрифтом принадлежат авторам статьи.

15 Там же. 
порядочных и достойных, в то время как бессовестные пребывают в покое и благополучии ${ }^{16}$

Я отчаянно, страшно виноват, даже не перед читателем, а прежде всего перед собственной совестью за ложь в своих повестях, которую так долго выдавал за правду, - словно бы говорит самим духом этой книги Л. Пантелеев, а в частности, «своей рукой вывел этот подзаголовок (т.е. что повесть «автобиографическая», как написано во всех ее изданиях). И вот теперь расплачиваюсь ${ }^{17}$.

Показательна лексическая сочетаемость (совесть: авторов, моя, собственная). В такой индивидуальной ответственности перед совестью возникает дистанция перед самим императивом совести, абстрактным ее понятием, не случайно совесть в публикациях журнала «Знамя» выступает как отделенная от человека высшая сила. Таким образом, нарративная реализация концепта «совесть» совпадает с узуальной моделью (общеязыковой), однако здесь мы наблюдаем интеллектуально-рационалистическое понимание совести, аналитически отделяющее норму, которая существует независимо от воли отдельного человека, и следование этой норме как идее.

Важно отметить еще один вектор нарративизации концепта «совесть» в дискурсе журнала «Знамя». Так, мы уже обращали внимание на появление нового, прагматически ориентированного смыслового компонента «форма организации деятельности высокого качества». Вследствие этого появился нарратив о добросовестном выполнении своих обязанностей («добросовестно»), о качественном, а не количественном соответствии нормам совести. Можно сказать, что, с одной стороны, добросовестность становится инструментом воплощения совести в повседневности, в сознании и деятельности индивида. С другой стороны, в ситуации ценностных трансформаций добросовестность выступает связующим звеном между лич-

\footnotetext{
${ }^{16}$ Е.П. Щеглова, Вера, истина, справедливость - и дочка Маша // «Знамя» 2016, № 4, http://znamlit.ru/publication.php?id=6242 (5.01.2019).

${ }^{17}$ Там же.
} 
ностным опытом и абстрактной категорией, устанавливает смысловые отношения.

Таким образом, «толстые» литературные журналы «Наш современник» и «Знамя», активизируют совершенно разные когнитивные модели (Т. ван Дейк) концепта «совесть». Первое издание предлагает борьбу за совесть, говорит о деградации этой ценности в современном мире, используя нарратив борьбы и столкновения двух сил. Второе издание репрезентирует совесть как личностную категорию и делает попытку найти связь между частным, индивидуальным опытом и идеей «совести», формируя нарратив «свободного выбора».

Нарративная реализация концепта «добро» активно используется в дискурсе журнала «Наш современник». В целом, она соответствует узуальной модели (общеязыковой), но трансформирует ядерный смысловой компонент «все положительное, хорошее, то, что противопоставлено злу». Так, выстраивается нарративная модель, в которой «добро» связано с памятью и прошлым, что позволяет говорить о противопоставлении добрых/недобрых (идей, качеств, людей), это порождает сюжет о «своих» и «чужих». Иными словами, с добром связано все, что соответствует ценностям и нормам, мировоззрению журнала «Наш современник», «добро» определяет право на существование, поскольку это высшая категория, ее не надо объяснять. Здесь важно подчеркнуть, что в дискурсе журнала «Наш современник» реактуализируются древнейшие смыслы концепта «добро», такие как «хорошо сделанный, правильный, соответствующий норме», что и позволяет применять этот концепт для установления легитимности и правильности чего-либо. Таким образом, формируется нарратив, построенный на оппозиции «мы»-«они», ее вариантах «свой»-«чужой», «законный»-«незаконный»:

Но это же кровное, воспитанное в нас «люди помогут!» движет нами, когда нам случается приходить на помощь другим, и даже сейчас, в паскудное время, когда целые синдикаты, эксплуатируя инвалидов, калек, малолеток, поставили на службу своего корыстного обогащения наши добрые искренние чувства, и люди, зная, что попрошайки, убогие, «инвали- 
ды», «люди неместные» - инструмент наживы в руках преступного мира, все равно тянутся к кошелькам, потому что помогать - не в сознании нашем, а в характере, в крови ${ }^{18}$.

В антитезе ему:

Сегодня России приходится фактически заново восстанавливать утраченное производство, вытеснять с отечественного аптечного рынка недобросовестных иностранных производителей ${ }^{19}$.

В дискурсе журнала «Знамя» мы обнаружили существование нескольких нарративных моделей, опишем самые частотные из них. Во-первых, это нарратив, в котором добро раскрывается как нравственно-этическая категория (добрый, добропорядочный, добросердечный и т. п.), качество человека. В таких текстах речь идет о возможности соответствовать человека гуманистическим ценностям. Во-вторых, истории о добре как некой норме социальной организации человеческой жизни (распространенное использование имени существительного «добро» и его лексических форм). В-третьих, апелляция к добру как условию признания чего-либо, то есть «одобрение». Существование этих трех нарративных вариантов вновь отсылает нас к «эгоцентрической» позиции, в которой человек сам отвечает за свои поступки, организует свой личный опыт. В этом смысле добро как некая норма репрезентирует абстрактно-философскую категорию, отделенную от повседневных практик простого человека, но присутствует как объективная идея. Тогда одобрение/неодобрение становятся проявлением воли, активного начала. Показательно, что в нарративе, где смысловой компонент «одобрение» играет важную роль, появляется критически-ироническое отношение к субъекту, проявившему свою волю:

${ }_{18}$ Т.Л. Миронова, Разговор по-русски - разговор по душам // «Наш современник» 2016, № 8, http://www.nash-sovremennik.ru/archive/2016/n8/160811.pdf (5.01.2019).

${ }^{19}$ И.Т. Янин, Блестящий сочинскийгамбит// «Наш современник» 2016, № 11, http://www.nash-sovremennik.ru/archive/2016/n11/1611-14.pdf (5.01.2019). 
Это антизападное поколение, смеющееся над западниками-либералами и одобряющее персоналистский режим Путина, по сути дела, первое самостоятельное независимое поколение с вполне западными бытовыми привычками и даже трудовыми навыками. Они хотят и умеют зарабатывать деньги с помощью напряженного квалифицированного труда ${ }^{20}$.

Иными словами, одобрение - действие, обнаруживающее волю человека и его способность соответствовать идеям добра, справедливости.

Таким образом, нарративная реализация концепта «добро» в журналах «Наш современник» и «Знамя» эксплицируют следующие когнитивные модели: добро как все законное, правильное, отличающее своих от чужих, и добро как нравственно-этическая категория, как выбор индивидуального сознания, проявление его воли.

Итак, дискурс «толстых» литературных журналов становится транслятором ценностных трансформаций в российском обществе. На примере когнитивной и нарративной реализации концептов «совесть» и «добро» можно сделать вывод, с одной стороны, о существовании ситуации культурного многообразия в современном русскоязычном медиапространстве, с другой стороны, о столкновении либерально ориентированной и консервативной систем ценностей.

Исследование выполнено за счет гранта Российского научного фонда (проект № 16-18-02032).

\section{REFERENCES}

Alefirenko, Nikolay F. Poeticheskaya energiya slova. Sinergetika yazyka, soznaniya. Moskva: Academia, 2002 [Алефиренко, Николай Ф. Поэтическая энергия слова. Синергетика языка, сознания и культуры. Москва: Academia, 2002].

Baryshnikova, Dar'ya V. "Kognitivnyy povorot v postklassicheskoy narratologii (Obzor novykh angloyazychnykh knig)." Novoye literaturnoye obozreniye, no. 119, 2013, www.magazines.russ.ru/nlo/2013/119/b32.html. Accessed 5 January 2019 [Барышникова, Дарья В. “Когнитивный поворот в постклас-

${ }^{20}$ С.В. Цирель, Что нас ждет? // «Знамя» 2016, № 9, http://magazines.russ. ru/znamia/2016/9/chto-nas-zhdet.html (5.01.2019). 
сической нарратологии (Обзор новых англоязычных книг).” Новое литературное обозрение, № 119, 2013, www.magazines.russ.ru/nlo/2013/119/ b32.html. Дата обращения: 5 января 2019].

Van Dijk, Teun A. Yazyk. Poznaniye. Kommunikatsiya: sbornik rabot. Ed. Transl. Gerasimov, Vladimir I. Ed. Petrov, Vasiliy V. Moskva: Progress, 1986. [Ван Дейк, Тен А. Язык. Познание. Коммуникаиия: сборник работ. Ред. пер. Герасимов, Владимир И. Сост. Петров, Василий В. Москва: Прогресс, 1989]. Fasmer, Maks. Etimologicheskiy slovar' russkogo yazyka. Transl. Turbachev, Oleg N. Moskva: AST-Astrel', 2007 [Фасмер, Макс. Этимологический словарь русского языка. Пер. Турбачев, Олег Н., Москва: АСТ-Астрель, 2007].

Gorbachevich, Kirill S. Slovar' epitetov russkogo literaturnogo yazyka. SanktPeterburg: Norint, 2002 [Горбачевич, Кирилл С. Словарь эпитетов русского титературного языка. Санкт-Петербург: Норинт, 2002].

Grekhneva, Larisa V., et al. Slovar' kontseptov russkoy narodnoy skazki: $v 2-k h$ ch. Nizhniy Novgorod: Izd-vo Nizhegorod. un-ta 2011, 2015 [Грехнева, Лариса В. и др. Словарь кониептов русской народной сказки: в 2-х ч. Нижний Новгород: Изд-во Нижегород. ун-та, 2011, 2015].

Karaulov, Yuriy N., et al. Russkiy assotsiativnyy slovar': v 2-kh t. Moskva: ASTAstrel', 2002 [Караулов, Юрий Н. и др. Русский ассоииативныцй словарв: в 2-x m. Москва: АСТ-Астрель, 2002].

Labov, William. Oral narratives of personal experience, http://ling.upenn. edu/ wlabov/Papers/FebOralNarPE.pdf. Accessed 5 January 2019.

L'vov, Mikhail R. Slovar' antonimov russkogoyazyka: boleye 2000 antonim. par. Moskva: Russkiy yazyk, 2001 [Львов, Михаил Р. Словарь антонимов русского языка: более 2000 антоним. пар. Москва: Русский язык, 1984].

Mareyeva, Svetlana V. "Dinamika norm i tsennosteyrossiyan." Sotsis, no. 7, 2013. [Мареева, Светлана В. “Динамика норм и ценностей россиян.” Социс, № 7,2013 ].

Maslova, Valentina A. Lingvokul'turologiya. Moskva: Izdatel'skiy tsentr "Akademiya," 2001 [Маслова, Валентина А. Лингвокультурология. Москва: Издательский центр “Академия," 2001].

Mironova, Tat'yana L. "Razgovor po-russki - razgovor po dusham." Nash sovremennik, no. 8, 2016, http://www.nash-sovremennik.ru/archive/2016/ n8/1608-11.pdf. Accessed 5 January 2019 [Миронова, Татьяна Л. “Разговор по-русски - разговор по душам.” Наш современник, № 8, 2016, http:// www.nash-sovremennik.ru/archive/2016/n8/1608-11.pdf. Дата обращения: 5 января 2019].

Ozhegov, Sergey I., Shvedova, Nataliya Yu. Tolkovyy slovar' russkogo yazyka: 80000 slov i frazeol. vyrazheniy. Moskva: Azbukovnik, 1999 [Ожегов, Сергей И., Шведова, Наталия Ю. Толковыий словарь русского языка: 80000 слов и фразеол. выражений. Москва: Азбуковник, 1999].

Schiffrin, Deborah. "Redoing and replaying." In Other Words: Variation in Reference and Narrative. Cambridge: Cambridge University Press, 2006.

Shcheglova, Yevgeniya P. "Vera, istina, spravedlivost' - i dochka Masha." Znamya, no. 4, 2016, http://znamlit.ru/publication.php?id=6242. Accessed 5 January 
2019 [Щеглова, Евгения П. “Вера, истина, справедливость - и дочка Маша." Знамя, № 4, 2016, http://znamlit.ru/publication.php?id=6242. Дата обращения: 5 января 2019].

Shkarovskaya, Iren V., Stanovleniye i razvitiye sovet.skikh "tolstykh" zhurnalov $v$ pervoy polovine 20-kh godov: avtoref. dis. kand. filol. nauk, Moskva 1999, http://cheloveknauka.com/stanovlenie-i-razvitie-sovetskih-tolstyh-zhurnalov-v-pervoy-polovine-20-h-godov. Accessed 5 January 2019 [Шкаровская, Ирэн В. Становление и развитие советских "толстых" журналов в первой половине 20-х годов: автореф. дис. канд. филол. наук. Москва 1999, http://cheloveknauka.com/stanovlenie-i-razvitie-sovetskih-tolstyh-zhurnalov-v-pervoy-polovine-20-h-godov. Дата обращения: 5 января 2019].

Slovar' russkogo yazyka: $v$ 4-x $t$. Ed. Yevgen'yeva, Anastasiya P. Moskva: Russkiy yazyk, Poligrafresursy, 1999 [Словарь русского языка: в 4-х т. Ред. Евгеньева, Анастасия П. Москва: Русский язык, Полиграфресурсы, 1999].

Slovar' sinonimov russkogoyazyka. Ed. Yevgen'yeva, Anastasiya P. Moskva: AST, 2003 [Словарь синонимов русского языка. Ред. Евгеньева, Анастасия П. Москва: АСТ, 2003].

Slovar' sochetayemosti slov russkogo yazyka. Ed. Denisov, Petr N., Morkovin, Valeriy V. Moskva: AST, 2005 [Словарь сочетаемости слов русского языка. Ред. Денисов, Петр Н., Морковин, Валерий В. Москва: АСТ, 2005].

Tilinina, Tat'yana V. "Prichiny krizisa tsennostnykh oriyentatsiy v sovremennykh rossiyskikh sem'yakh." Teoriya i praktika obshchestvennogo razvitiya, no. 6, 2012, http://teoria-practica.ru/rus/files/arhiv_zhurnala/2012/6/sociologiya/ tilinina.pdf. Accessed 5 January 2019 [Тилинина, Татьяна В. “Причины кризиса ценностных ориентаций в современных российских семьях." Теория и практика общественного развития, № 6, 2012, http://teoria-practica.ru/ rus/files/arhiv_zhurnala/2012/6/sociologiya/tilinina.pdf. Дата обращения: 5 января 2019].

Tsirel', Sergey V. “Chto nas zhdet?” Znamya, no 9, 2016, http://magazines.russ. ru/znamia/2016/9/chto-nas-zhdet.html. Accessed 5 January 2019 [Цирель, Сергей В. “Что нас ждет?” Знамя, № 9, 2016, http://magazines.russ.ru/ znamia/2016/9/chto-nas-zhdet.html. Дата обращения: 5 января 2019].

Yanin, Igor' T. "Blestyashchiy sochinskiy gambit." Nash sovremennik, no. 11, 2016, http://www.nash-sovremennik.ru/archive/2016/n11/1611-14.pdf. Accessed 5 January 2019 [Янин, Игорь Т., “Блестящий сочинский гамбит.” Наш современник, № 11, 2016, http://www.nash-sovremennik.ru/archive/2016/ n11/1611-14.pdf. Дата обращения: 5 января 2019].

Yanin, Igor' T. "Chernomorskaya Pal'mira." Nash sovremennik, no. 9, 2016, http:// nash-sovremennik.ru/archive/2016/n9/1609-14.pdf. Accessed 5 January 2019 [Янин, Игорь Т. “Черноморская Пальмира.” Наш современник, № 9, 2016, http://nash-sovremennik.ru/archive/2016/n9/1609-14.pdf. Дата обращения: 5 января 2019].

"Znamya:" ocherk istorii, http://znamlit.ru/history.html. Accessed 5 January 2019 [“Знамя:"очерк истории, http://znamlit.ru/history.html. Дата обращения: 5 января 2019]. 